\title{
Developing Learning Media of Réception Orale Débutant using Smart Apps Creator Application
}

\author{
L T Pawani ${ }^{1}$, H Fibriasari ${ }^{2}$, R Ramadhani ${ }^{3}$, P Sembiring ${ }^{4}$ \\ 1,2,3,4 Foreign Language Department, Faculty of Languages and Arts, Universitas Negeri Medan, medan, Indonesia \\ Universitas Negeri Medan, Indonesia \\ Email: lellytatripawani@gmail.com ${ }^{1}$,hestifibriasari@ymail.com², reniramadhani@unimed.ac.id ${ }^{3}$,
}

pengadilensembiring@unimed.ac.id

\begin{abstract}
This study aims to develop learning media of réception orale débutant using Smart Apps Creator application for 2nd semester students and to determine the feasibility of the learning media developed. This research uses research and development (R\&D) methods. ADDIE development model which consists of 5 stages, namely problem analysis, product design, media development, product design validation and product design revision. The initial stage in this research is collecting data by analyzing needs using google forms, designing and creating learning materials, and validating them to material experts and media experts. The data and data sources in this study are data regarding the feasibility of learning media that have been validated by the validator, the data sources in this study are students as informants in needs analysis questionnaires and books, articles, journals as supporting other data. Data analysis technique in this research is data collection with percentage analysis instrument. The results of the validation test by material experts are $80 \%$ and media experts are $90 \%$. The results of material validation are "good" category and the results of media validation are in the "very good" category. It can be concluded that the learning media developed using Smart Apps Creator application is declared valid for use in learning French for 2nd semester students
\end{abstract}

Keywords: Learning media, Debutant, Smart apps

\section{INTRODUCTION}

Media is a presentation of material using words and pictures. The meaning of the use of the words Mayer meant is that the material is conveyed in verbal form, for example using printed or spoken words, while the use of images according to Mayer is that the material is presented. in fictitious form or as an image. Static graphic forms (including illustrations, graphics, photos and maps) or using dynamic graphics (including animations and videos). Then, in textbooks, words can be presented as printed text and images can be presented as illustrations or other classification forms [1].

Learning media is an important component in learning, so it can be a source of reference in addition to the material presented by the teacher. Learning media is an inseparable part of the teaching and learning process in order to achieve educational goals. So far, there have been many emerging learning media, both conventional and digital media, but not many multimedia-based learning media are used in the learning process. The use of interesting learning media can increase new interests and enthusiasm so as to motivate them to continue learning. By using interesting and appropriate learning media, learning objectives can be achieved properly.
The interactive learning model is a student-oriented learning model (student centered), where students are directly involved in various types of learning activities in the classroom. Interactive learning model makes students interact with each other in doing and thinking (hands on and minds on) which produces direct feedback on the subject matter given [2].

In language learning there are four language skills, namely réception orale, réception écrite, production orale and production écrite. The four skills cannot be separated from each other. Oral reception is an important element in learning, especially French. By practicing regularly, students will have experience and knowledge of correct pronunciation, increase vocabulary, correct structure, and proper sentences when speaking. To develop these competencies, students must learn to "use knowledge and strategies related to speaking and listening in many diverse interactions" [3].

Réception orale is the ability to make meaning from listening to a statement. It is an active and complex process for a second language (foreign language) learner. "The listener must be able to discriminate between sounds, understand vocabulary, interpret accent and intonation, and get used to the rhythm of a language 
other than their native language. Then he will have to retain what has been understood in order to interpret it in the immediate context as well as in the larger sociocultural context of a text or a statement. It goes without saying that coordinating all of these processes requires a complex mental exercise on the part of the listener. Listening comprehension is difficult and therefore deserves more attention and study. For learners, there are linguistic difficulties associated with listening such as learning a new phonetic system, the inability to decipher the flow of speech, and difficulty understanding the spoken forms of the words they know. in their written form [4]. One of the learning materials in the reception orale débutant course is "se presenter". This material was chosen as material to be developed in this research because this material is the basic material that beginner French learners must master. In this material, we learned the conjugation of être and avoir, s'appeler, habiter, age, profession, et nationalité.

Based on the results of observations made using a need analysis questionnaire for second semester students majoring in french in Universitas Negeri Medan on December 1, 2020, in oral comprehension learning or called réception orale débutant, teachers use learning media in the learning process. The learning media used are books, audio-visual media such as Power Point, and internet media or websites. In using these media, students still need various media to improve listening skills in the réception orale débutant course. So a variety of interactive and varied learning media is needed.

In this study, the interactive learning media that will be used is the Smart Apps Creator (SAC) application. By using this application, the teacher as a facilitator can provide teaching materials using interactive teaching aids that are interesting and effective. Smart Apps Creator (SAC) is an application for creating multimedia applications based on mobile, desktop and web. Because the development results can be converted into Android/IoS mobile applications, desktop applications without programming code, and HTML5 web applications that can be accessed via a browser.

Smart Apps Creator was chosen because this application has never been used as a medium for learning French in particular in the course from Beginner Oral Reception to the French section Universitas Negeri Medan. This application also has many advantages, namely by using this application one can create applications without programming knowledge, then one can export html5 projects. Besides building the app, it turns out that the smart app builder can also upgrade to html5, and not only that the smart app builder can also export to the windows app in .exe format. The appearance of this application is easy to understand, almost the same as Photoshop, so if Photoshop is mastered, this application will be easier to understand.

By using this media, teachers can include material accompanied by pictures, audio, video and animation so that they can increase students' motivation in learning, especially in the réception orale débutant course in semester 1 of the French language education study program of Universitas Negeri Medan.

\section{THEORETICAL BACKGROUND}

\subsection{Foreign Language Learning}

Learning is the result of ignorance of the mechanism, which occurs in one person and is most likely influenced by others [5]. Learning is mastery or acquisition of a subject or a skill through learning, experience, and education [6]. The foreign language is a subject that develops oral and written communication skills to understand, reveal information, feel thoughts, and develop technological and cultural knowledge [7]. Based on the above description, it can be concluded that foreign language learning is a process of language learning with the aim that students can communicate verbally and in writing both individually and in groups.

\subsection{Reception Orale Débutant}

Based on the CEFR (Common European Framework of Reference for Languages), the level of learning French in language skills is made up of six levels, namely: the introductory level (A1), the level intermediate (A2), threshold level (B1), advanced level (B2), autonomous level (C1), mastery (C2). However, if it is observed that these six levels can be subdivided from the classical division into three levels, namely the basic, intermediate and advanced levels (basic level, intermediate level and advanced level), then these levels are offered in three general levels. Levels which each have two subsections, namely basic or beginner user (A1 and A2), independent user (B1 and B2) and experienced user ( $\mathrm{C} 1$ and $\mathrm{C} 2)$. in order to learn to listen, students must be able to perform a series of listening activities, including: Receive statements (auditory perception skills), Identify linguistic messages (language skills), Understand the message (semantic skills), Interpretation of messages (cognitive skills) [8].

If students are unable to master the four listening activities, it can be interpreted that students will have difficulty learning to listen, i.e. difficulty receiving utterances (auditory perception skills), difficulty identifying linguistic messages (language skills), difficulty understanding messages (semantic skills) and difficulty interpreting messages (cognitive skills).

\subsection{Learning media}

\subsubsection{Definition of learning media}

Media are often referred to as a mediator, that is, the cause or tool that intervenes between two parties and 
reconciles them. The term media mediator designates his function or role, namely to regulate the effective relationship between the two main actors in the learning process. The learning media is a tool that is physically used to convey the content of the learning material, which consists of books, tape recorders, cameras, cassettes, videos, recorders, films. , television, slides, photos, graphics and computers. The definition of media in general is a component of learning resources or physical means that contain educational material in the student environment that can stimulate students to learn. Purpose of the learning materials is to facilitate communication and learning. Educational media has the meaning of an in-classroom or out-of-the-classroom learning program tool that is used in the context of communication, interaction of teachers and students in the learning process. The learning materials can be used in large numbers, in large groups, in small groups or individually [9].

\subsubsection{Benefits and functions of learning media}

The use of educational media in the teaching and learning process can generate new desires and interests, generate motivation and stimulation of learning activities. and have a psychological influence on students [10].

The benefits of media learning according to Kemp and Dayton are as follows: Provide learning according to standards, make learning more interesting. learning is more interactive, the duration of the lesson can be shortened, the quality of learning outcomes can be improved, education can be given anywhere and anytime, increase students' positive attitude towards the learning process.

In addition, Levied and Lentz suggest four functions of teaching aids, especially visual media, there are: the function of visual media attention is primarily to attract and direct the attention of students to focus on content related to visual meaning or accompanying text, the affective function of visual media can be seen to delight students while studying text with pictures, the cognitive function of visual media can be seen from the results. The study found that visual symbols or images facilitate achievement of the goals of understanding and memorizing information or messages that are in the image, the compensation function of the learning medium can be seen from. The conclusion is that visual media provide a context for understanding text to help students who are poor in reading organize information as text and remember.

\subsection{Media Smart Apps Creator}

Smart Apps Creator (SAC) is digital interactive media used to create multimedia applications based on mobile, desktop and web. Because development results can be converted into Android / IOS mobile apps, desktop apps without programming code, and HTML5 web apps accessible through browser. The advantage of smart app builder is that you can build apps without programming knowledge, then you can export HTML5 project. besides creating the app, it turns out that smart app builder can also switch to HTML5, and not only that smart app builder can also export to windows app in .exe format, 1 The appearance of this app is easy to understand, almost the same as Photoshop, so it's not too difficult to use if you use Photoshop often.

\subsubsection{The advantages of Smart Apps Creator}

\subsubsection{Can do applications without programming knowledge}

In general, it is necessary to create an application as program code, but using Smart Apps Creator support, application development does not require programming code, so application development becomes easy and instant.

\subsubsection{Can export HTML5 project}

Besides creating apps, it turns out that smart app builder can also switch to HTML5. Not only that, the smart app builder can also export to Windows app in .exe format

\subsubsection{Easy to understand display}

The display of Smart Apps Creator is very easy to understand. It will be easier for users to understand how Smart Apps Creator works and tools if they are already familiar with Photoshop.

\subsubsection{Doesn't take a lot of RAM}

This application can be downloaded to a laptop or notebook as it does not take up much space. So that when it is executed it will not be slow.

\subsubsection{Shortcomings of the Smart Apps Creator,}

Indonesian is still not available in Smart Apps Creator, Not suitable if used on Android, This app can only be used on laptop or computer. if you want to download it from cell phone playstore, it will be different, This app can only create an app with simple results, Difficult to understand if not familiar with computers.

\section{METHOD}

\subsection{Research Method}

The method used in this research is research and development (R\&D) method. Research and development methods are methods used to produce products and test the effectiveness of these products. 
The research method used in research on the development of learning media in the reception orale debutant course using the Smart Apps Creator application is a qualitative method. The research steps used are the ADDIE development model (analysis, design, development, implementation, and evaluation) by Dick and Carey [11]. However, in this study, the implementation stage only reached the development stage due to time constraints and conditions that did not allow it. The steps of the Research and Development $(\mathrm{R} \& \mathrm{D})$ research procedure based on the ADDIE model are as follows:

\subsubsection{Analysis}

Analysis is an early stage of development. The analysis stage is a need assessment process, identifying problems and performing task analysis. This stage is carried out to obtain information about the needs of learning media. This analysis was carried out by distributing a needs analysis questionnaire using google form to the second semester students of the French language education study program in Universitas Negeri Medan.

\subsubsection{Design}

The second stage to be carried out is design. At this stage all designs are prepared, starting from the material design, the software used, and the planning flow. This design will form the basis for the next development process.

\subsubsection{Development}

At this stage, the media development process is carried out by realizing product designs, namely by designing learning materials using predetermined software, namely smart apps creator software. Then consult the supervisor to carry out the next stage, namely validation. Implementation of this validation is done by asking for help from media experts and material experts. As a validator to know the level of eligibility. Validators provide comments, ratings and suggestions about the developed media. Based on the results of the assessment carried out by the validator, it is used as a reference for revising the product so that the developed media can be improved and is suitable for use as a whole.

\subsection{Data Collection Technique}

The data collection technique used in this study was a questionnaire. Questionnaire is a data collection technique that is done by making questions to respondents to be answered. This questionnaire was created using google form. In this study, documents are also needed as a supporting source so that this research can be carried out. Documents used at the design and development stage are sources from articles, journals, books and the internet related to the research to be carried out.

\subsection{Research Instruments}

In this study, the research instrument was used to determine the feasibility of interactive learning media created using the smart apps creator application based on the assessment of the validator. This instrument is filled out by means of a checklist on each indicator to determine the feasibility level of the learning media made.

\section{RESULTS AND DISCUSSION}

In this study the development model used is ADDIE Analysis, Design, Development, Implementation, Evaluation. But due to time constraints and unfavorable conditions. adequate, only three steps were changed, namely: Analysis, Design, and Development. The steps include: collecting data and problems using a needs analysis questionnaire, product design, product development and design validation.

\subsection{Analysis}

Before developing media, we must first analyze the problem. To find out the problem, a needs analysis was carried out by distributing questionnaires via google form to 20 second semester students of the French language education study program who studied in the reception orale débutant course.

Based on the results of the needs analysis questionnaire distributed to 21 students, the following data can be obtained:

- There were $85 \%$ of students who stated that learning French was difficult to learn, then 15\% stated that learning French was easy.

- $95 \%$ of students stated that during the learning activities in the reception orale débutant course, the lecturer used the media in delivering the material, and $5 \%$ of the students stated that they did not.

- $15 \%$ of students stated that the media used in the previous lesson had helped in understanding the material in the reception orale débutant course. While the other $85 \%$ said they still need interesting and varied media.

- $55 \%$ of students stated that the use of learning media was very important, $15 \%$ stated it was important,

- For the selection of materials that need to be developed using teaching media in the Orale débutant Reception Course, $75 \%$ of students chose the presenter material, $20 \%$ of students chose the Donner des informations sur soi material, $20 \%$ chose the Aborder quelqu'un material, 5\% chose Demander un renseignement material, $20 \%$ chose Découvrir une ville material, $20 \%$ chose 
Rencontrer les membres d'une famille material, $30 \%$ chose son temps organizer material, $20 \%$ chose Prendre de nouvelles habitudes material, $15 \%$ chose s'adapter un rythme de vie, $20 \%$ chose Répondre une invitation, $5 \%$ chose faire face un problème, and $10 \%$ of students chose Faire un pique-nique material.

- The location of students' difficulties in French, especially in the réception orale débutant course, $35 \%$ of students stated that they were not accustomed to listening to French audio, 35\% of students stated that they lacked French vocabulary, and $30 \%$ of students stated that they did not understand French pronunciation with Correct.

- All students have one of the computers, laptops, and smartphones.

- $90 \%$ of students stated that it is very helpful if there is a smartphone-based media that can explain the material interactively and interestingly to help students in the process of learning French. While the remaining $10 \%$ said it was normal.

- all students have never heard of Smart Apps Creator media

- nothing is known by all students about media smart apps creator

- $80 \%$ of students said that media smart apps creator can be used for learning reception orale débutant

- Some student opinions about the development of learning media in the reception orale debutant course, among others, sound interesting, will increase student learning motivation, it is very good if it can help add variety to learning.

Based on the results of media analysis using a de Besoin analysis questionnaire, it can be concluded that media development using the smart apps creator application will be able to help students in the learning process in the reception orale debutant course. Based on the explanation of the results of the questionnaire, it is necessary to develop presenter materials designed in the form of applications using smart apps creator media that can be used inside or outside the classroom using Android.

\subsection{Design}

The design stage is an important stage before carrying out the product development stage. At this stage, the media design is carried out which includes the preparation of the overall media design from start to finish. The media design stage carried out includes the preparation of materials and practice questions, as well as designing the media by preparing backgrounds, images, audio, video and animation. The product designs designed are:
Making this learning media design serves as an overall guide to facilitate the process of making media.

\subsubsection{Determining the material}

The material chosen to be developed is a presenter. This material is determined based on the students' most choice in the needs analysis questionnaire so that the results of the media development carried out are in accordance with the student's needs and produce good and suitable products for use. In this media, videos and audio related to the material presented by the presenter will be presented as well as practice questions to train students' understanding of the material presented.

\subsubsection{Media Material Collection}

Before the media is developed, the materials to be included in the media are collected first. These materials include backgrounds, navigation button icons, images and animations as well as video and audio.

\subsection{Development}

The development stage is carried out after all the planning designs are made and then realized at this stage. In making this media there are several components that are worked on, namely cover, material title page, main menu, learning objectives, dialogue, material, grammar, vocabulary, and exercise. These stages can be broken down as follows:

\subsubsection{Cover}

This page is the initial display of the media containing the subject, the name and number of the media developer, the name of the supervisor, as well as Universitas Negeri Medan's logo.

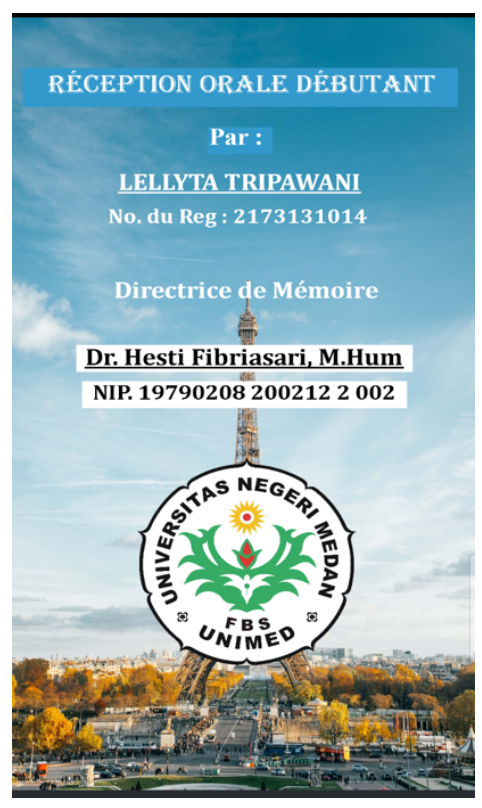

Figure 1. Cover Display

\subsubsection{Design of learning media}




\subsubsection{Material Title Page}

This page is the page that appears after the cover. This page contains the title of the material, namely "Se Présenter", images and animations related to the presenter, and at the bottom of the page there is a start button for commands to start using the application.

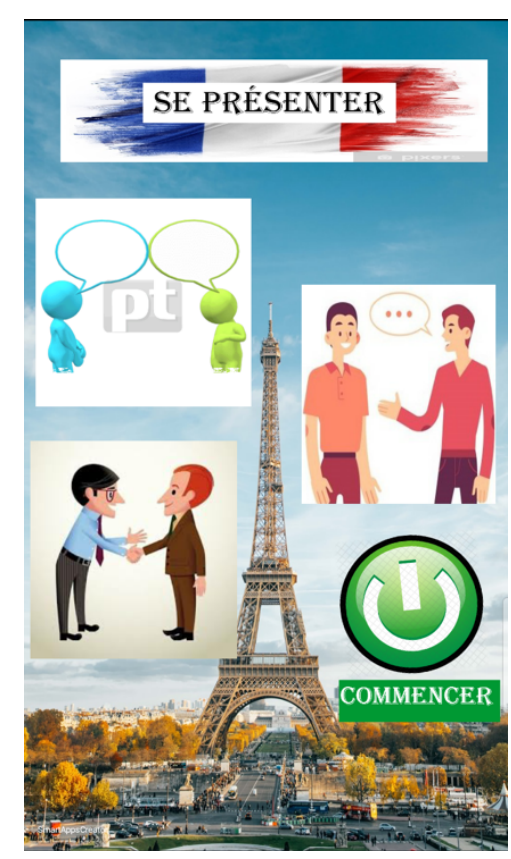

Figure 2. Title Page

\subsubsection{Menu Principal}

On this page the main menu contains all the menus in the application such as objective d'apprentissage, dialogue, material, gammaire, vocabulaire, and exercise. All buttons and menu options on this page have been activated, so when one button or menu option is clicked it will open the next page as desired.

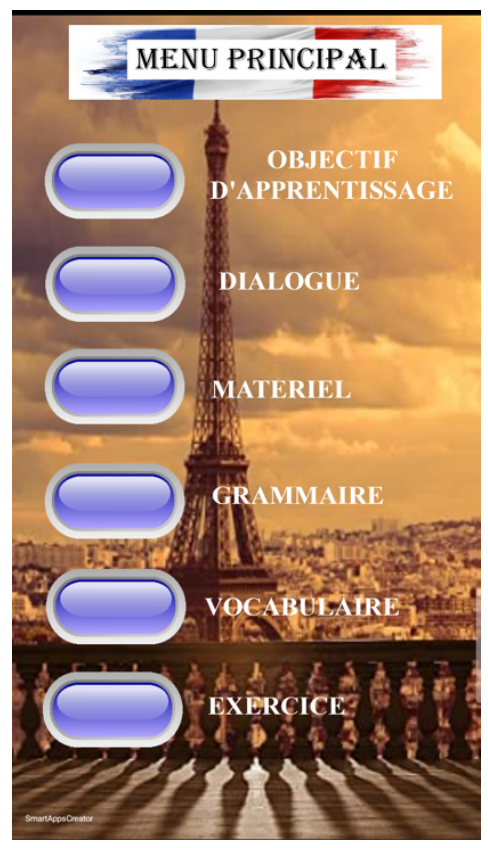

Figure 3. Main Menu Display

\subsubsection{Objectif d'Apprentissage}

On the learning objective page, the content of this page contains learning achievements, competencies/ability for each learning stage, and learning objectives. This page will open when clicked on the objective d'apprentissage button or menu option on the main menu page.

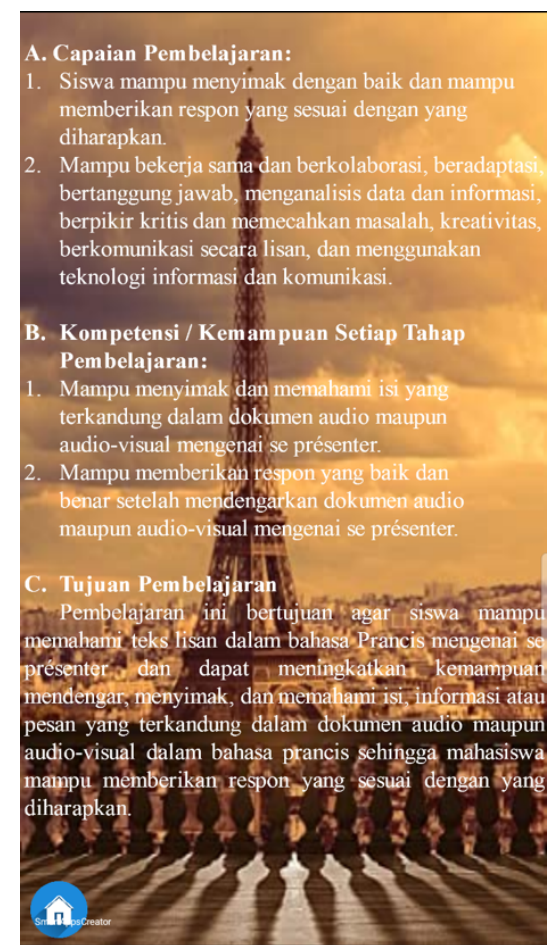

Figure 4. Learning Objective Display

\subsubsection{Dialogue}

On this page, there are video dialogues about conversations about the presenter's material. The video is taken from the source of the book tendance A1 and Echo A1. 


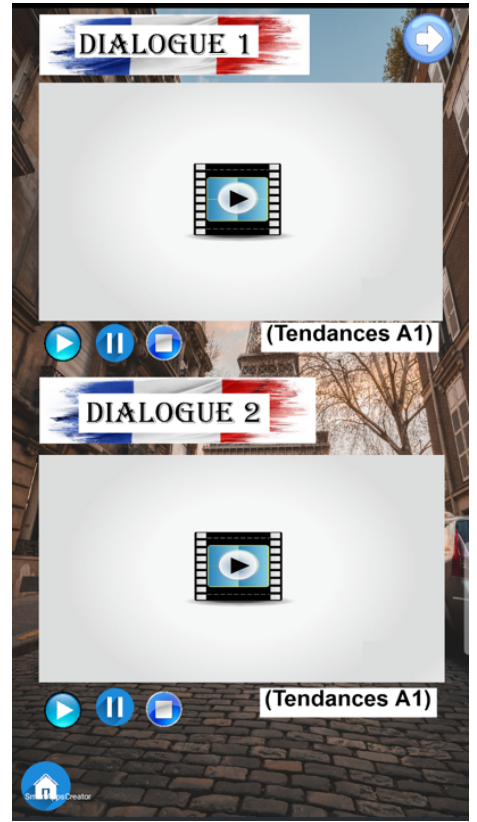

Figure 5. Dialogue Page

\subsubsection{Material}

This page contains materials that are presented in accordance with the selected material, namely the presenter. The material is presented in detail starting from les noms et prenoms, les nationalités, l'âge et date de naissance, les professions, et les scolarisés.

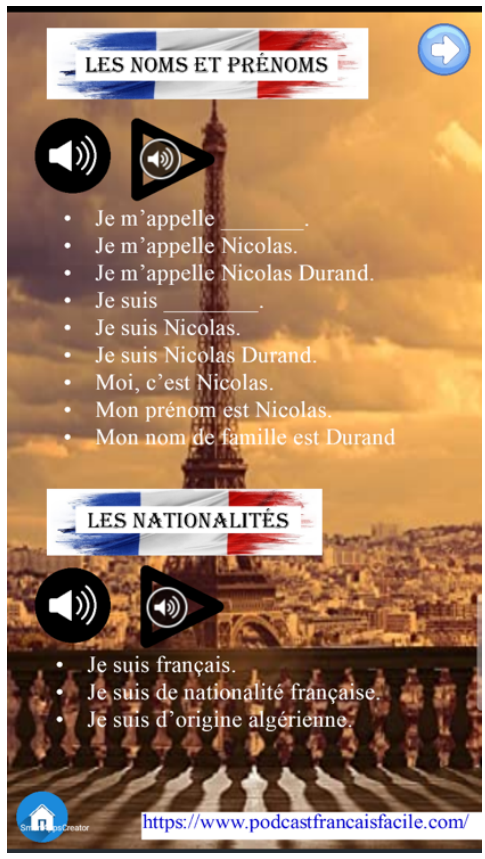

Figure 6. Material Page

\subsubsection{Grammaire}

On this page, the content contains grammar used in the presenter material, namely conjugaison des verbes tre, avoir, s'appeler, et habiter.

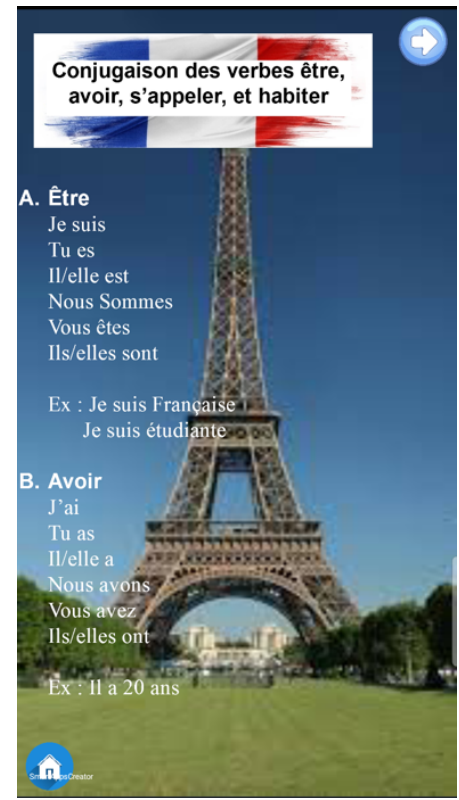

Figure 7. Grammar Page

\subsubsection{Vocabulaire}

On this page, there are vocabulaires related to the presenter's material, namely les nationalités et les professions. In vocabulaire les nationalités, the difference between pays, habitans et capitals is presented. Meanwhile, in vocabulaire les professions, the division of masculin and feminine terms in professions and the correct pronunciation is presented.

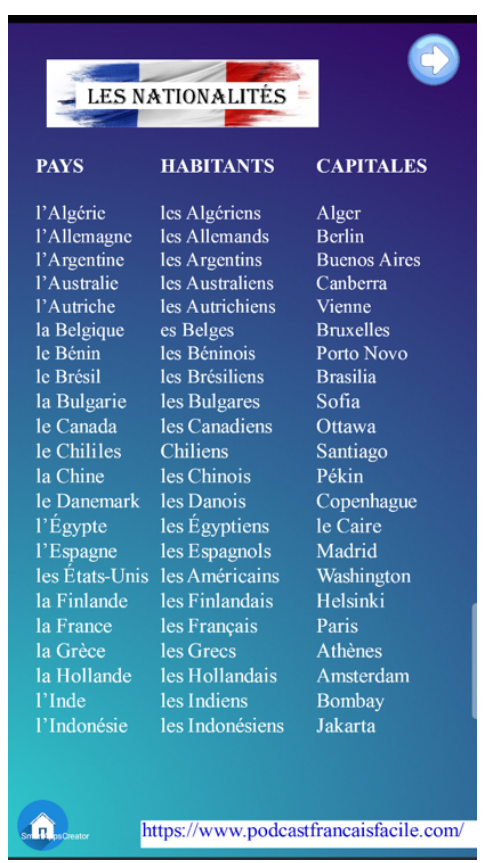

Figure 8. Vocabulary Page

\subsubsection{Excercice}

On this page, there are practice questions containing audio that must be listened to first, then the questions below must be answered. The form of the questions 
presented are vrai ou faux questions and questions that must be answered based on the audio that is listened to.

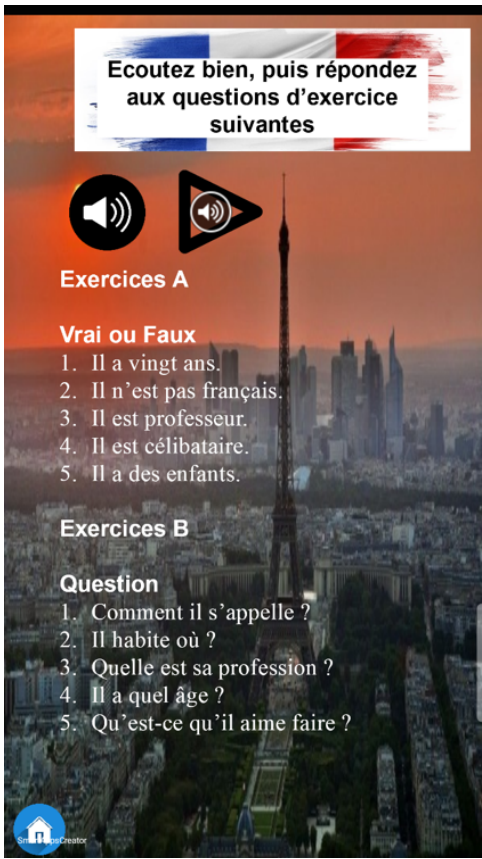

Figure 9. Exercise Page

\subsection{Validation}

The next step after the media has been created is the feasibility test. The media that has been made is then validated by material experts and media experts. Each validation will provide a better product evaluation. at this stage, the validator provides comments, suggestions and corrections on this media, both the advantages and disadvantages of this media. This development stage produces teaching material products in the form of learning media that have been reviewed based on comments and suggestions from both material validators and media validators.

\subsubsection{Validation by learning material expert}

The validation of this material aims to determine the opinion of the material validator on the feasibility of content, language feasibility, and presentation feasibility. This validation was carried out by Dr. Hesti Fibriasari, M. Hum, professor of UNIMED. The evaluation was carried out in order to obtain information about the quality of teaching materials developed to improve the quality of learning in the French section of Universitas Negeri Medan, especially in the réception orale débutant course on "se presenter" material. The results of the validation and assessment of material experts on each aspect of the overall assessment are determined by their respective scores and average criteria. The results of the validation by the validator above show that the presenter material developed includes the "good" criteria with a score of 80 and the percentage result is $80 \%$. This can be seen from the scores obtained. The comments and suggestions given by the material validator are "the developed learning media has a display that matches the background and color, but the selection of fonts in writing should be legible and clearly written". That is, the learning media developed has a display that matches the background and color, but the selection of fonts in the writing should be legible and clear. Based on these results, it can be concluded that the material from this learning media can be used.

\subsubsection{Validation by learning media expert}

Validation on this media aims to determine the opinion of the media validator on the feasibility of media presentation. The feasibility of the developed media is known from the results of expert validation. Media validation was carried out by Dr. Surya M. Hutagalung, M.Pd, a professor at Universitas Negeri Medan. The media that has been validated by the expert is then revised based on the suggestions given by the validator.

The validation of the learning media developed includes two aspects. Namely aspects of media characteristics and aspects of media display. The results of the validation by the media validator above show that the media developed includes the "very good" criteria with a score of 90 and the percentage result is $90 \%$. This can be seen from the scores obtained. Thus, the total score obtained is $90 \%$ in the "very good" category where the media is designed according to the learning materials that are arranged in an interesting and creative way. The comments and suggestions given by media experts were "the choice of color and background is appropriate, but on the dialogue page, the video that is playing does not have a play and stop button so that the video that is playing cannot be stopped manually. So it is necessary to add a play and stop feature to every video." Based on these results, we conclude that this learning media can be used with revisions according to the suggestions of the media validator.

\subsection{Research Analysis}

This learning media will be developed and used in the learning process on the presenter material for the debutant level. The developed media is applicationbased using a smartphone. This media contains learning objectives, dialogues related to the presenter material, descriptions of material containing several audios that discuss the presenter, grammar related to the presenter, namely the conjugation of tre, avoir, s'appeler, et habiter, vocabulaire related to presenter material to increase student vocabulary, as well as practice questions.

The end result of the development of this media is a learning application that can be used by teachers and students in order to facilitate the learning process and increase learning variations both in the classroom and outside the classroom. Learning materials and learning media were revised based on the results of the test of material experts and media experts. This learning media creates physical and mental activities that must be 
carried out by students in the learning process, with the aim that students are able to understand spoken texts in French about the presenter and can improve listening, listening, and understanding the contents of audio and video documents in French. so that students can respond as expected.

\section{CONCLUSION}

Based on the results of the study, it can be concluded that the product developed in this study is a learning media in the reception orale debutant course in the form of an application using the media smart apps creator. Based on the evaluation of media experts and material experts who have calculated to obtain the ideal score, this learning media is suitable for use in learning. The design of learning media must pay attention to the presentation of information, use of media, ease of use. After these aspects are fulfilled, the media begins with: (1) opening page, (2) title page, (3) main menu page, on the main menu page there are several menu options such as: objective d'apprentissage, dialogue, material, grammar, vocabulaire and exercise.

The results of validation by two experts, namely material experts and media experts indicate that the learning materials and learning media produced are suitable for use. The results of the expert validation above for the feasibility of presentation show that the feasibility of presenting the learning materials developed is $80 \%$ included in the "good" criteria. This can be seen from the scores obtained. The validation results were obtained from the aspect of the content of the learning material studied $(80 \%)$. The evaluation results show that the indicators evaluated on these aspects are good. The results of expert validation for the feasibility of the media showed that the feasibility of the developed learning media was $90 \%$ included in the "very good" criteria. This can be seen from the scores obtained. We examine the validation results obtained from aspects of media characteristics and aspects of media appearance $(90 \%)$. The evaluation results show that the indicators evaluated in these aspects are very good.

\section{REFERENCES}

[1] Mayer, Richard E. 2009. Multimedia Learning. Yogyakarta: Pustaka Pelajar.

[2] Hake, Richard R. 1997. Interactive-Engageent Versus Traditional methods:A six thousand student survey of mechanics test data for introductory physics course.

[3] MÉLS (ministère de l'Éducation, du Loisir et du Sport). 2011. Progression des apprentissages au primaire. Québec : Gouvernement du Québec.

[4] Vandergrift, L., Goh C. 2012. Teaching and learning second language listening: Metacognition in action. ESL \& Applied Linguistics Professional Series. Routledge.

[5] Tagliante, C. 2005. Techniques et Pratiques. Paris : CLE International.

[6] Brown, H. Douglas. 2007. Principals of Language Learning and Teaching. USA: Longman.

[7] Depdiknas. 2003. Undang-undang Republik Indonesia Nomor 20 Tahun 2003 tentang Sistem Pendidikan Nasional. Jakarta : Biro Hukum dan Organisasi.

[8] CECRL (Cadre European Commun de Reference pour les Langues). 2000. Stasbourg : Unité des Politiques linguistiques.

[9] Arsyad, Azhar. 2011. Media Pembelajaran. Jakarta: Raja Grafindo Persada.

[10] Dick, Walter, Low Carey and James Carey. 2009. The Systematic Design of Instruction. New Jeresy: Perason. 